\title{
Trade Unions and the State in Solomon Islands
}

\section{Ian Frazer*}

Among small island states of the South Pacific, Solomon Islands has the third largest trade union movement after Papua New Guinea and Fiji. Unionism had an uncertain start in the early 1960s, then became more firmly established with the formation of the Solomon Islands General Workers Union in 1975. This union, which later became the Solomon Islands National Union of Workers, took a more militant and political approach to getting recognition for unionism and improving working conditions. This regularly put it into conflict with the state as well as employers. More recently it has been joined by two large public sector unions, just as militant in their wage negotiations and ready to confront the power of the state. The growth of unionism and the conflicts which have arisen out of this show the way in which emergent class formation is proceeding.

\section{Introduction and background}

In the last three years there has been a rapid escalation in militant action by trade unions in Solomon Islands. In 1989 a long-running dispute between the government and the Solomon Islands National Teachers' Association (SINTA) reached a head with a three month long national teachers' strike, one of the longest and largest stoppages in Solomon Islands labour history. The teachers were pursuing a fight to bring their pay scale into alignment with the general public service pay scale. More recently there has been a bitter dispute between Solomon Mamaloni's government and the Solomon Islands Public Employees Union (SIPEU). It began in September, 1990 when the government changed the conditions of service for its Permanent Secretaries, putting them on four year contracts, increasing their salaries by 118 percent, and offering a range of extra gratuities and benefits. The SIPEU reacted angrily, opposing the new contracts and demanding an equivalent increase in salary for the rest of the public service. Strike action took place in November 1990. A new and much longer strike started in April 1991, after the government withdrew its recognition of the SIPEU claiming that the union had not fulfilled the requirements of its constitution. This strike, reported to involve up to 4000 civil servants (Solomon Star, 31 May 1991), lasted nine weeks although not all stayed out over the whole period. Public servants got a 16 percent pay increase during the strike. The disagreement over recognition and the SIPEU's opposition to the new contracts for Permanent Secretaries continued for the rest of the year. In November, 1991 , following reports that the government was in a serious financial crisis with foreign reserves at a record low level, there was a call from the Solomon Islands Council of Trade 
Unions (SICTU) for Solomon Mamaloni's resignation from office accompanied by the threat of a large national strike. ${ }^{1}$

As these events suggest, Solomon Islands has a very strong and politically active union movement. After Papua New Guinea and Fiji it is now the third largest movement among independent countries of the South Pacific. The 18 registered unions claim to have a membership of 19,500 which is 75 percent of the enumerated workforce of $26,000{ }^{2}$ Within the union movement, the SIPEU, with an estimated 3000 members, and the SINTA, with 2500 members, are the second and third largest trade unions, coming some way behind the Solomon Islands National Union of Workers (SINUW) which at the end of 1990 claimed a paid-up membership of 13,000 representing around 50 percent of the total enumerated workforce. $^{3}$ On the figures given, these three unions account for 93 percent of unionised workers. All the other unions representing the remaining seven percent have less than 300 members. Most of them are made up of groups of employees, often professional or managerial staff, belonging to only one enterprise, government department or statutory authority. They include nurses, doctors, senior police officers, electricity workers, pilots, and prison officers.

The growth of unionism has taken place in a country in which there has been limited development of wage employment. Solomon Islands continues to depend heavily on agriculture. The majority of people live in villages and practise mixed subsistence and commercial production. The main exports are timber, fish, palm oil, copra and cocoa. There is some small-scale manufacturing and processing, mostly based in Honiara. The employment provided by all these industries with the commercial sector and a large public sector gives an enumerated workforce which is still only 18 percent of the working age population (15-54 years) (Central Bank of Solomon Islands, Annual Report, 1990). This relatively small workforce is also highly mobile with a lot of movement in and out of employment, and between different workplaces.

In view of the small size of the workforce and its mobility, proletarianisation has not been seen as a strong trend in the Solomon Islands and there has been little interest in the history of organised labour (Connell and Curtain, 1982; Connell, 1983). ${ }^{4}$ Solomon Islanders are seen as rural people strongly attached to their place of origin: their village, language group, and island. Ethnic ties are seen as taking precedence over class relations; rural links are seen to preclude full dependence on wage employment.

This paper takes the view that it is misleading to perpetuate this picture when the evidence also shows a growing commitment to employment and dependence on wage employment. Over the last 30 years there has been a steady increase in the size of the wage labour force (from 8000 in 1960 to 26,000 in 1990), in its concentration in and around

\footnotetext{
'Information on industrial disputes between 1989 and 1991 comes from the Solomon Star, Solomon Nius and Solomons Toktok newspapers for that period.

${ }^{2}$ November 1990, Registrar of Trade Unions. Total membership is an estimate based on information provided by union officials. The workforce total comes from the Central Bank of Solomon Islands, Annual Report, 1990.

${ }^{3}$ The SIPEU total is a conservative estimate. Actual membership was contested when the Government withdrew recognition in 1991. In one report SIPEU claims 4000 (Solomon Star, 31 May 1991). The SINTA and SINUW figures were given by union officials.

‘ Two recent histories of the Solomon Islands make little reference to trade union history (see Bennett, 1987; Laracy, 1989).
} 
Honiara (up to 60 percent of the enumerated workforce are employed on North Guadalcanal), and in its stability. These trends are significant enough to represent the emergence of an urban-based working class. Some of the strongest evidence for this comes from the growth of organised labour, as seen in the history of collective action to improve wages and working conditions, including several large general strikes. Early unionism was weak and its future uncertain but by the 1980 s this had changed and it had become a powerful industrial force. In view of this, the idea that Solomon Islands still has a largely migratory labour force is drastically in need of revision.

The main aim of this paper, as a contribution to this revision, is to outline the history of Solomon Island unionism, giving attention in particular to the timing and form of union organisation. The paper will finish by looking at contemporary unionism and relating this to emergent class formation. The period being dealt with here only goes back as far as the first attempts at organisation in the 1950s and early 1960s. The history of labour relations prior to this has already been well documented (Bennett, 1987). The combination of a very paternalistic and repressive colonial state, a plantation economy that relied on indentured labour migration, and a small, uneducated, poorly skilled and ethnically divided workforce, precluded the formation of workers' associations. Wages and other conditions of work were laid down by regulation and were not open to collective negotiation. Occasional protests and disputes took place on plantations and in other workplaces, and a very disruptive recruiting boycott was organised under the Maasina Rule movement in the late 1940s (Frazer, 1990), but it was not until the administration lifted its coercive labour policy in the final years of colonial rule that workers were allowed to form their own trade unions.

When unionism first began, the labour market that had existed until that time was being transformed under the influence of British aid, which was then being used to raise the level of social and economic development in the territory. The policy that was pursued required a large and expanding state structure (Hughes, 1988, p.5). It also led to heavy investment in Honiara where most of the new bureaucracy was situated. That policy was maintained up to and after independence, as the bureaucracy was localised, and as successive governments continued to increase the size of the state. Even when there was a large influx of private capital in the early 1970 s, much of this involved joint ventures with the state and did not reduce its dominance in the economy. Neither did it ameliorate the concentration of employment; key investments in agriculture were located on the Guadalcanal Plains just out of Honiara. By 1988, just over half of the enumerated workforce was employed by central and provincial government, statutory authorities and nationalised industries; one-third of all formal employment was located in Honiara (Solomon Islands Statistical Bulletin No 16/89; Hughes, 1988).

Unionism has been strongly influenced by the relative size of the public sector and by the heavy concentration of employment in Honiara. Government employees did not have a monopoly on organisation; private sector workers have also been prominent in the history of the movement. Government employees did have the advantage of being heavily concentrated in Honiara and dealing with an employer that wanted to set a good example in industrial relations. The government could not so easily avoid recognition and negotiation as private employers.

\footnotetext{
s 1960 workforce total from Annual abstract of statistics, 1970; the estimate of those employed in North Guadalcanal from Solomon Islands statistical bulletin, 12/91; evidence for stability in Walsh, 1990.
} 
Another important influence on unionism was the kind of encouragement that was given to workers, by the government in particular, to become more stable in employment. One of the main reasons for that encouragement was to raise the level of skill and expertise within the workforce, there being a severe shortage of skilled labour as national development proceeded. The government made itself the pace-setter in providing the necessary incentives. In doing so it did not want to lose control of the overall level of wages and overly distort differences in income between those in paid employment and those in rural areas. One way in which it tried to maintain that control was to create an internally segmented labour market. The better educated and skilled were recruited as established employees or civil servants. They were given the best pay, working conditions and job security of all government employees. Behind them came lesser skilled manual workers, known as the non-established. They were sub-divided again according to their skill and training.

Civil servants and non-established workers have always organised separately. In the early years of labour unrest and union activity, non-established workers were much more militant than civil servants. It is only in recent years that civil servants have made themselves the most militant group within the union movement. In the past it was more common among lower paid government workers, especially in the large general strikes that took place in Honiara in the early 1960s and mid-1970s. Civil servants did not join those strikes. In the context of wage disparities that made the difference between being able to stay on in employment or returning to the village, those who were on the borderline had the most to fight for. They were the ones who played the most prominent part in the rise of organised labour, in combination with those who were below them. The rise of organised labour threatened government's control of that borderline and many of the struggles over wage increases may be seen in that light.

These changes provide the immediate background to the beginning of unionism and the workplace struggles with which unions became involved. It can be seen from this that the state set in train a restricted form of proletarianisation, except that, being largely skilled state employees, it was not a true proletariat that was being formed. Neither was it a united one. Civil servants saw their interests differently from all other government employees including other skilled workers who subsequently came to organise with the unskilled and low paid.

\section{The 1950s and 1960s: unionism under the colonial state ${ }^{6}$}

The early history of attempts to organise within the civil service can be dealt with very briefly. Except that it helped to affirm their separation from the rest of the workforce, it was not a major influence on the beginning of unionism. When the British Solomon Islands Civil Servants' Association (BSICSA) was formed in 1954 it was dominated by expatriates. The Association adopted the same racial division that existed in the civil service (and the rest of the workforce), with a separate branch for Solomon Island members.

The early years of the Association are notable for long periods of inaction, broken only when there was a review of the civil service. One such review, by Mayle, took place in 1960, and another in 1968-69 by Pincombe. This latter review is important because it

\footnotetext{
${ }^{6}$ Most of this section is taken from Frazer, 1986.
} 
marks the occasion when expatriate civil servants left and formed their own organisation, and Solomon Islanders took over the Association. By this time they not only outnumbered expatriates, they were impatient to speed up the process of localisation. The Pincombe review reaffirmed the differences in their salaries and this was a continuing grievance. Under Solomon Islanders' control, the BSICSA was a much more active and outspoken organisation but its effectiveness suffered through the high turnover of the executive and their movement into politics or to the higher levels of the civil service (Frazer, 1986; Tuhanuku, 1984, pp.81-82).

Organisation of workers outside the civil service began in the early 1960 s, when the number of people in paid employment was not much above the levels reached in the plantation era. Except for the small number of skilled employees, the majority of workers were being paid and treated as bachelor migrants. The first trade union was formed among stevedores and copra workers. It was registered in 1961 and called the British Solomon Islands Workers Union (BSIWU). In 1963 it became the British Solomon Islands Ports and Copra Workers Union (BSIPCWU). In the same year another union was formed to represent unskilled and semi-skilled workers in Honiara, the British Solomon Islands Building and General Workers Union (BSIBGWU). A strong group within that union were government non-established workers.

The short period in which these unions were active was a particularly turbulent time for industrial relations. There were two general strikes in Honiara and a third strike by workers of the largest private company in the Solomons, Levers Pacific Plantations Limited. The unrest was not brought about by the unions themselves but by the tactics used by government and private employers to avoid serious collective bargaining. This soon drove a wedge between union leaders and the rank and file and effectively destroyed all credibility for unionism.

Both unions were established with the advice and assistance of the Department of Labour and its Commissioner of Labour. They remained under that influence even though they were well off financially and could afford to support their own full-time officials and a central office. This compromised them so badly it inhibited them from using strike action, the only real power that they had in their attempt to gain recognition and pursue negotiations.

After registration, it was 18 months before the BSIWU negotiated two agreements with employers, one with the Ports Authority and the other with Levers. The long delay in getting an agreement built up disaffection with the union. This got worse as the membership demanded a second round of negotiations. Levers, in particular, ignored these demands so in September, 1964, their workers took action into their own hands and struck. The strike spread to most of Levers' plantations, with 933 workers stopping work, some 80 percent of the company's labour force. It lasted eight days before it was broken and the majority returned to work. What helped Levers to break this strike was its policy of hiring a more compliant ethnic group (Tikopians) and using them to divide the labour force. Nothing was achieved by the strike. The union was then banned from Levers' estates. It did negotiate another agreement with the Ports Authority on behalf of stevedores but by then had no support to keep going.

There was a similar experience with the BSIBGWU and its members working in town. Their confrontation arose with the government on behalf of its non-established workers. After delaying negotiations for eight months, there was a secret agreement with union leaders offering a wage increase considerably less than what was being demanded. When the membership found out they also struck, precipitating a general strike throughout Honiara. It started on 1 April 1965 and spread to other government workers in Yandina, Munda and 
Gizo. Around 1,500 workers struck and stayed out for eight days. The government broke the strike by threatening to sack the strikers and repatriate them to their homes. An estimated 20 percent of strikers did not return to work. Nothing was gained through the strike and the union closed down soon afterwards.

The 1965 general strike was the second major stoppage in Honiara in three years. An earlier general strike in 1962 was not union-led. The leadership and the majority of strikers were government non-established workers. They were protesting specifically about the discriminatory provisions in the Mayle Award, a new wages and salary award for all government employees which was released in October, 1962. The award gave expatriate civil servants a 20 percent increase, local civil servants 13 percent, and non-established workers 10 percent. All government non-established workers plus many others struck without warning at the end of the month. More than 1,100 workers struck and stayed out until they negotiated the same 20 percent increase as expatriate civil servants. Significantly, local civil servants did not join this strike under pressure from the government.

The early 1960s were an object lesson for aspiring union leaders that in years to come was heeded to good effect. In the meantime, the colonial state reinforced its power over organised labour by bringing in comprehensive new legislation for the control of trade unions (The Trade Unions Ordinance No 4/1966).

\section{The 1970s: the beginning of independent unionism}

It took ten years before unionism recovered from the events of 1964-65. The recovery, which was unexpected and unassisted, brought a completely new kind of unionism to the country. In particular it was politically driven and for a short period it threw the government and industrial relations into turmoil.

The years from 1966 to 1974 were relatively quiet for industrial relations. There were a number of small disputes confined to particular workplaces but none which led to wider strike action. Civil servants demonstrated over a pay claim in 1972 (British Solomon Islands, News Sheet, 16-30 November 1972). There were several unsuccessful attempts to revive unionism including one by Peter Salaka, who represented Honiara in the Governing Council.

The Labour Department used this void to push joint consultation "with varying degrees of success" (Solomon Islands, Annual Reports, 1973; 1974). Workers who participated in this felt the lack of power. ${ }^{7}$ It was a period in which the value of wages fell in relation to price increases, there was a chronic shortage of housing (marked by a rise in the number of squatter settlements, some of them formed by married government employees), workers received few extra allowances or benefits and many grievances were ignored.

Wary of attempts to revive unionism, the government, in 1973, produced its own guidelines. These were little more than thinly disguised joint consultation and continued to reflect the colonial approach to containment. Unions should not try and organise nationally but remain small, confined to one trade or profession, and remain non-political. They should elect their own leaders and avoid full-time officials. ${ }^{8}$ There were three unions registered in

\footnotetext{
7 Interviews with Public Works Department employees, 1974.

- Memo prepared for the Governing Council by the Chairman of the Local Government Committee, 12 December 1973 (Solomon Islands National Archives).
} 
1974 and early 1975 which were largely in keeping with this policy: the Government Workers' Union which later became the Government Non-Established Workers' Union (GNEWU), the Guadalcanal Plains General Workers' Union (GPLGWU), and the Solomon Islands Public Servants Association (SIPSA), formed out of the old BSICSA (Solomon Islands, Annual Report, 1975).

The initiative for a new and more independent kind of unionism started in early 1975. Rather unpredictably it came from outside the workforce and outside the government, from an economics graduate of the University of Papua New Guinea, Bartholomew Ulufa'alu, who was one of the few university graduates at that time to return to the Solomons and forgo automatic entry into the public service. He was joined by Joses Tuhanuku who also had tertiary training in Papua New Guinea at the Lae University of Technology. They originally met through their involvement in student politics in Papua New Guinea, an experience which had a strong influence on their approach to unionism. They formed the Solomon Islands General Workers' Union (SIGWU), later to become the Solomon Islands National Union of Workers (SINUW). By working full-time for the union, organising nationally across all industries and sectors, being willing to use militant tactics and adopt political objectives, their aims and methods represented a complete break with government policy.

Ulufa'alu and Tuhanuku started off by organising for six months in the labour lines and at public meetings. This helped to lay the basis for subsequent solidarity action when they eventually sought recognition for the union. Ulufa'alu concentrated in particular on his relatives (wantoks) from the Langa Langa and West Kwaio area of Malaita, people with long experience of labour migration and industrial action.

The SIGWU had its greatest impact between July 1975 and February 1976. The period started off with a dispute over recognition when the union set out to represent stevedores working for the Ports Authority. Known as a tough employer more inclined to replace its labour in the event of disagreements rather than negotiate, the Authority delayed recognition and negotiations. The stevedores struck and after one week they were joined by more than 1,300 other workers in Honiara in a show of solidary action. This included many essential workers which immediately threatened basic services in town and forced the government to become involved (Solomons News Drum, 30 August 1975).

Attempts to resolve the dispute began with the appointment of a one-man Commission of Inquiry into the cause of the stevedores' strike. The union ignored this move because it offered no assurance of any decision over their request for recognition, no protection for the stevedores or recommendations on their behalf. After the strike had been running for two weeks, the Chief Minister in association with his Council of Ministers entered into direct negotiations with the union. After a week-end of negotiations it was agreed that an arbitration tribunal would be appointed to hear the stevedores' case, the stevedores would get compensation for the time that they were off work, special consideration would be given to essential workers when legal action was taken against them; and the government would assist the union in obtaining recognition from other employers (Solomons News Drum, 5 September 1975). When the Tribunal brought down its findings in October, 1975, it granted the stevedores a substantial wage increase ( 20 percent for senior stevedores, 25 percent for junior stevedores) and strongly recommended changes in labour legislation and the appointment of a Labour Advisory Committee (Solomons News Drum, 31 October 1975).

The dispute with the Ports Authority and the associated general strike gave Ulufa'alu and the SIGWU maximum publicity in Honiara and throughout the Solomons. There was a rush of interest in joining the union and in pushing for negotiations with other employers. With this advantage a more ambitious round of action started soon afterwards culminating in 
another much larger general strike. The main basis for this action was a move to amalgamate all existing unions, with the exception of the SIPSA, into one Amalgamated National Workers' Union (ANWU), seek recognition for the new union from all medium and large employers, and confront them with a comprehensive log of claims made up of 57 political and industrial demands. The government tried to stop this action by refusing to register the ANWU using a clause in the constitution of the SIGWU. Ulufa'alu and other leaders of the ANWU ignored this and proceeded to ask for recognition from all employers anyhow, demanding negotiations under threat of strike action (Solomons News Drum, 21 November 1975; 12 December 1975).

Simultaneously the SIGWU organised political demonstrations in Honiara. There was a protest march on 26 November and another illegal march on 11 December. After the second march, six union officials were arrested as leaders of an illegal protest and later fined. Two who refused to pay their fines, Ulufa'alu and James Maefa'alu (President of the GNEWU) were subsequently sent to prison. There was another big demonstration on the day of internal self-government, 2 January, 1976 (Solomons News Drum, 5 December 1975; 19 December 1975; 9 January 1976; Tuhanuku, 1983, pp.122-123).

The day of self government was also when the threatened general strike began. At the start, 4,300 workers stayed away from work, representing 70 to 80 per cent of workers employed in Honiara and on the Guadalcanal Plains. The strength of support here shows the kind of impact made by the SIGWU in the six months which it had been operating. For the government, this and the continuing political agitation brought a crisis of strange proportions: a generalised dispute over recognition directed at a large number of employers, accompanied by a complex log of claims with 57 items representing both political and industrial demands, carried out in the name of an unregistered union, whose leader was in prison. Such a dispute could not be ignored, yet fitted none of the available conciliation procedures. It forced the government to intervene even more than it had done previously. Their action in this case finally halted moves to amalgamate existing unions, but it did ensure that individual unions, including the SIGWU, got recognition from a large number of the employers originally targeted by them and, in many cases, ended up negotiating collective agreements with them. Government streamlined the log of claims by ignoring all the political demands and reducing it to 28 industrial items. Some agreements were reached in the first week of the strike. By 12 January more than half the striking workers had returned to work. More agreements in the second week of the strike meant that most workers then returned to work. By late January, Ulufa'alu was claiming to have completed talks and negotiated agreements with 22 companies with more negotiations still proceeding (Solomons News Drum, 9 January 1976; 16 January 1976; 27 February 1976).

The events of 1975-76 had precedents in the large Honiara strikes of 1962 and 1965. Again there was generalised support from large numbers of public and private sector workers. Again, civil servants refused to join. The 1976 strike was the last time that general strike action would take place. There has been frequent militant action since then but it has been confined to single industries or companies, or to single professional groups like the teachers and civil servants. The reasons for this can be found in changes which were made in industrial legislation in 1976 introducing compulsory arbitration and penalties for 'unlawful' strikes (Trade Disputes Act 1976); and changes in the tactics adopted by trade unions, being more selective with sympathy strike action. At one level, the 1975-76 action shows the frustration that had built up among workers unable to negotiate effectively over working conditions and not having leaders who were a match for the bosses and bureaucrats of Honiara. At another level, these events mark a decisive break with the past, with the failures 
of the 1960 s and with the constraining influence of colonial control. It was as if unionism went through its own transition to independence immediately before the rest of the country.

\section{Unionism and the post-colonial state}

The events of 1975 and early 1976, had a profound influence on the future development of the union movement and on Solomon Islands industrial relations. The SIGWU went on from this to become the largest union in the country, with the strength and commitment to bring about a steady improvement in working conditions for a wide range of employees in many different industries and workplaces (Keith-Reid, 1983). It also went on to form a political party, the Nationalists' Party, later to become the National Democratic Party (NDP), and campaign in the 1976 general elections. Each of these developments came to be closely identified with one or other oi the two main leaders of the SIGWU. Tuhanuku took responsibility for the industrial side, Ulufa'alu the political side. Only Tuhanuku stayed with unionism in the long-term.

The NDP won eight seats in the elections of 1976 , three seats in 1980 and one seat in 1984. It ceased to exist in 1986 when Ulufa'alu renamed it the Solomon Islands Liberal Party (Solomon Nius, 14 August 1986). By that time it no longer had any ties with the union movement. Ulufa'alu served in parliament as the leader of the NDP for two terms losing his seat in 1984. He was Leader of the Opposition in his first term, and in 1981 became Minister of Finance as part of the coalition government led by Solomon Mamaloni. The NDP never had enough power in parliament to influence industrial legislation and if that was the main reason for forming a political party in the first place, as Tuhanuku claims (1983, p.26), it did not get very far.

For the SIGWU, the first venture into politics was nearly disastrous. The temporary suspension of the union in late 1977 under allegations of mismanagement and misappropriation of funds, and its loss of credibility and effectiveness, has been described by Tuhanuku (1983, pp.127-128). He returned earlier than he intended from training in Denmark and set about rebuilding the union starting among plantation workers. By securing some good agreements with major companies, he succeeded in putting the union back on its feet.

While Tuhanuku credits plantation workers for ensuring the recovery of the union it was urban workers who were to get the greatest benefit from collective negotiations, especially government non-established workers. SIGWU support for these workers started in 1975 when they joined the short-lived ANWU. The SIGWU then helped the GNEWU to negotiate a collective agreement with government in 1976. It subsequently absorbed the GNEWU. The success of wage negotiations is shown by a starting wage in 1980 for a government labourer of $\$ 74$ per month when the urban minimum wage was still $\$ 31$ per month and rural workers were getting less through not being covered by the minimum wage award. ${ }^{9}$ Non-established workers numbered 2,200 in 1980 and included a large number of skilled and semi-skilled, many of them acquiring their skills on the job rather than through formal training. Their commitment to employment came early in the growth of Honiara and this made them keen to see their working conditions improve. Starting in 1976 the collective

\footnotetext{
Government submission to the arbitration tribunal in the dispute between the SIGWU and Solomon Islands Government over a new award for government non-established workers, March 1981 (Solomon Islands National Archives).
} 
agreements negotiated by the union show an increasing number of benefits and allowances - holiday pay, sick pay, travelling allowances, better housing allowances - in keeping with this trend. Unions were not just representing the emerging working class they were also helping to create it.

In this regard, the SIGWU/SINUW fought on a wide front, not just acting on behalf of more privileged sectors of the labour force like non-established workers, but taking on small and large companies throughout the private sector. It also fought for the non-unionised as well as the unionised by arguing for a higher minimum wage. The SINUW led the way in seeking affiliation with international trade union organisations. In 1980 it obtained full membership of the International Federation of Plantation, Agricultural and Allied Workers and the World Federation of Trade Unions (WFTU) (Tuhanuku, 1983, p.129). There were trips to Moscow and meetings of the WFTU by Tuhanuku, Ulufa'alu and other officials (Tuhanuku, 1983; News Drum, 29 May 1981). The SINUW also played a role in the development of regional trade union links, attending meetings of the Pacific Trade Union Conference, later to become the Pacific Trade Union Forum and then the Pacific Trade Union Community. Tuhanuku was extremely active in the fight for a nuclear-free Pacific and in attacks on colonialism (Robie, 1986).

As the SINUW increased in strength and effectiveness there were renewed attacks on it and on unionism generally. The strongest attacks came from government, concerned that it was losing the battle to hold down wages. In pursuing that battle, the government relied mainly on labour legislation as the best way in which to contain collective bargaining. This included the law relating to trade unions, introduced in 1966 and reinforced by successive amendments, and the law relating to essential services, which was gradually extended to include a wider range of services.

The law that has had the greatest impact on industrial relations in the 1980 s has been the Trade Disputes Act 1981 (which replaced the Trade Disputes Act 1976). Originally based on the Fiji Trade Disputes Act 1973, the main change that this brought about was to introduce compulsory arbitration. The intention was to limit the impact of industrial disputes and speed up conciliation and arbitration procedures (News Drum, 10 April 1981). The 1981 Act took this further by setting up a Trade Disputes Panel made up of a Chairman appointed by the Judicial and Legal Service Commission, and an equal number of union representatives and employer representatives. The requirement that its decisions must take account of 'the economy as a whole' allows for considerable flexibility in interpretation. The Act makes it very easy for disputes to be referred to the Panel and consequently it has come to be used by employers as a way for avoiding serious negotiations. The number of cases being referred to the Panel has steadily increased (The Nius, 7 August 1987).

The SINUW opposed the Trade Disputes Act when it was introduced in 1981 and was highly critical of the Trade Disputes Panel as soon as it began operating (News Drum, 27 November 1981; Government Monthly, June 1985). Tuhanuku accused it of favouring employers. To the extent that it was able to restrict wage increases his criticisms are well-founded. Early on in its deliberations the Panel put forward the principle that it would be wrong to calculate wages by reference to workers' domestic needs alone, disregarding the type of work (News Drum, 18 December 1981). With this kind of principle it had no trouble acting as a brake on wage increases. Adjusting wage demands according to the ability of businesses to pay allowed it to withstand SINUW's fight to reduce wage disparities between industries and enterprises (Keith-Reid, 1983). Another principle that came to be used by the Panel was restricting wage increases to two-thirds of movement in the Retail Price Index. Other decisions of the Panel were not all against unions. On several occasions in the early 
1980 s it recommended the introduction of a check-off system and this came to be accepted by many employers to the advantage of unions.

Throughout the 1980 s, the SINUW continued to be the largest and strongest union in the Solomons. At the same time it was joined by the SIPEU (formerly the SIPSA) and the SINTA as two other professionally organised and run organisations. In the last six years these two unions have come to occupy the centre stage in industrial relations. The Public Employees' Union began its rise to prominence in 1982, the Teachers' Association in 1985. Both unions strengthened themselves by starting active recruiting campaigns, appointing full time union officials, setting up central offices, pursuing links with international union organisations, and, more recently, forming their own credit unions; both took a more combative stance to negotiations over wages and other conditions of service. The beginning of militant action was a large stoppage of civil servants in late 1984 over the late payment of a wage increase (Government Monthly, November 1984). Since then it has regularly pursued major wage increases for civil servants. The SINTA grew out of earlier unsuccessful attempts to form a national teachers' union (Galo and Pelobule, 1986, p.14). Teachers had previously tried to join the SINUW but were thwarted by the law preventing government employees from joining non-governmental unions. Besides pursuing regular wage increases, the union took as one of its central issues the fight to restructure teachers' pay in line with that of the public service.

Of the two large public sector unions, civil servants have pursued the more independent line within the union movement. They have been prepared to work in with other public sector unions but have been more cautious about cooperating with the SINUW. One of the main differences between them has been disagreement over international affiliation. The SIPEU opposed the SINUW's affiliation with the WFTU, not so much for ideological reasons than because it objected to any kind of manipulation by international organisations (Waghorne, cited by Leckie, forthcoming). Whether or not SINUW was being manipulated, and this is doubtful, such a stand did not prevent SIPEU from seeking its own international support from organisations like the Asia American Free Labour Institute (AAFLI), Public Service International (PSI) and Postal Telegraph and Telephone International (PTTI) (Solomon Nius, 29 May 1987; 6 May 1988).

This division between the SINUW and the SIPEU was brought on more by rivalry between their respective officials than deeply held ideological differences. Yet it has not prevented cooperation in areas of mutual interest, notably in the most recent dispute with government over the new contracts for Permanent Secretaries.

What is particularly significant about contemporary unionism under the influence of the three largest unions is their strong involvement in politics. SINUW made another attempt to unify the union movement and form a political party soon after the demise of the National Democratic Party. In 1986 a large number of unions joined to form the Solomon Islands Council of Trade Unions (SICTU). One of the first actions of the Council was to boycott a government-proposed Economic Summit at which it was intended to discuss a wage freeze and public service redundancies (Solomon Nius, 4 September 1986). Not long after the SICTU was formed it proceeded to organise the Solomon Islands Labour Party in time to contest the 1989 general elections. The Labour Party manifesto offered much more for trade unions than any previous political party, including promises to see disputes settled through negotiations and to replace the Trade Dispute Panel with a tripartite Conciliation and Arbitration Commission (Solomon Islands Labour Party, Manifesto, 1988). Tuhanuku became the first President of the Labour Party and was one of two candidates to win seats in the National Parliament. He has now become Leader of the Opposition. Given the present 
instability of parliamentary politics, the Labour Party could become part of a coalition government but even that prospect would still be a long way from a Labour government.

The record of union involvement in politics only shows that they are unable to muster much political support outside the very small number of constituencies in which workers are concentrated. Only a small number of unionists have won seats by standing in their home area and the union movement still has to find some other way of expanding its political base.

Political activity has not been restricted to election campaigns and parliamentary politics. In many other ways unions have represented one of the strongest countervailing forces in national politics through the 1980s. Much of their action has been directed at governments of the day, sometimes on the basis of poor performance, especially poor economic management, sometimes over specific issues. A lot of this action can be summed up as protest against the accumulation of power and the abuse of power by politicians and bureaucrats. The SINUW led a march of 2000 unionists in Honiara in 1981 soon after the Kenilorea government voted in new salary increases for members of parliament (News Drum, 8 May 1981). The SIPEU engaged in a long campaign from 1983 onwards against the sale of government houses which they saw as being open to abuse. ${ }^{10}$ In 1985 , their protest action forced then Prime Minister Peter Kenilorea to institute a Commission of Inquiry and subsequently to sack one of his cabinet ministers implicated in irregularities over the sale of houses. The SINTA was prominent in uncovering alleged corruption by government personnel and private individuals involved in the World Bank Primary Education Project in the mid 1980s (The Report of the Commission of Inquiry into the World Bank Primary Education Project, 1988).

Notwithstanding these and other protests, the concentration of power in the post-colonial state has proceeded. Because of its large size and its pivotal role in the national economy the state became what Sandbrook $(1985$, p.67) describes as the "principle instrument of personal advancement". Those who came to power at independence took over colonial economic policy and then became the main beneficiaries of it. The people to benefit from these opportunities were at the highest levels of the state structure - cabinet ministers, top civil servants, constitutional post holders, executive officers, managers and directors of public agencies and public enterprises. Advancement to these positions began in the early 1970s in the lead-up to independence. It speeded up as localisation proceeded and the state continued to expand. Besides the obvious advantage of higher salaries, special allowances, access to the best government housing and vehicles, and numerous other perks, these political insiders have been able to use their power in other ways to augment their earnings and control of assets. Many top politicians and bureaucrats have gone on to become wealthy businessmen and landlords in Honiara.

This process of dominant class formation through the auspices of the state, is now well advanced. It must be kept in mind that class relations in this situation "are determined by relations of power, not production" (Sklar, 1979, p.537). It is not that a pre-existing ruling class seized the opportunity for local accumulation at independence; rather a political elite has used its power to pursue economic prosperity (Sandbrook, 1985, p.68). It is now well on the way towards becoming a ruling class. As this paper has shown, class formation in Solomon Islands has not been confined to a new dominant class; new subordinate classes are emerging as well, including in particular an urban based working class. Both dominant and subordinate

${ }^{10}$ Reported in the Solomon Star, Solomon Nius, 1983-1986. 
classes are still very weak because of the short history of economic and political change, because of the fluidity of present power relations and because ethnic and regional divisions are still very strong.

Trade unions have, on occasions, provided a useful political base for movement into the elite as happened with the SIPSA, with the SIPEU, and with the SINUW. More importantly, trade unions, are a good indication of the level of solidarity within the new working class, and its capacity for organisation and collective action. They are also an important indication of the way in which class struggle has developed. A lot of the union action which has been described can be interpreted in general terms as protest against the newly emerging dominant class. The fact that unions have not simply restricted themselves to fighting for basic industrial concerns shows that they have a good understanding of the new relations of power within which they are situated.

\section{Conclusion}

The history of unionism in Solomon Islands spans the creation of a larger, more stable and more concentrated workforce. By rejecting the colonial model of industrial relations a distinctive form of unionism was established, sufficiently professional and autonomous to ensure effective collective negotiations and also ensure it would survive and grow in strength. The exceptionally high level of union membership and the high level of cooperation between different unions means that unionism has become a powerful political force in relation to the post-colonial state.

Unions have won many industrial battles through the 1980s. They have also found other ways of providing benefits for their members and strengthening their membership. This includes setting up credit unions, providing health insurance and starting superannuation schemes. Politically they have not succeeded in preventing the increasing accumulation of power by a new political elite. The danger is that as trade unions continue their efforts to do this, they will find that power being used more severely against them. There are signs of this already with the withdrawal of recognition from the SIPEU in 1991. This suggests that the political battles in which unions are now engaged could become more intense and threatening to them, particular if the state becomes increasingly authoritarian. 


\section{References}

Bellam, M.E.P. (1970), The Colonial City: Honiara, a Pacific Islands Case Study, Pacific Viewpoint, 11(1): 66-96.

Bennett, J.A. (1987), Wealth of the Solomons, A History of a Pacific Archipelago, 1800-1978. Honolulu, University of Hawaii Press.

Central Bank of Solomon Islands (1982-1990), Annual Reports, Honiara.

Connell, J. (1983), Migration, Employment and Development in the South Pacific, Country Report No 16, Solomon Islands, Noumea, South Pacific Commission.

Connell, J. and Curtain, R. (1982), Urbanization and Inequality in Melanesia, In R.J. May and H. Nelson (Eds) Melanesia: Beyond Diversity, Canberra, Research School of Pacific Studies, The Australian National University.

Frazer, I. (1986), Trade Unions and the Struggles of Solomon Islands Workers in the Early 1960s, South Pacific Forum, 3(1): 60-96.

Frazer, I. (1990), Maasina Rule and Solomon Islands Labour History, In C. Moore, J. Leckie and D. Munro (Eds) Labour in the South Pacific, Townsville, James Cook University of Northern Queensland Press: 191-203.

Friesen, W. (1989), Migration, In K. Groenewegen (Ed) Solomon Islands Report on the Census of Population 1986. Report 2.B: Data Analysis, Honiara, Statistics Office, Ministry of Finance.

Galo, C.K. and Pelobule, U. (1986), The Solomon Islands National Teachers' Association History and Challenge, In Strengthening of Teacher Unions in the South Pacific, Suva, Report of the First IFFTU/FES/FTU Regional Seminar for the South Pacific Teacher Unions.

Hughes, A.V. (1988), Climbing the Down Escalator. The Economic Conditions and Prospects of Solomon Islands, Canberra, National Centre for Development Studies, A.N.U.

Keith-Reid, R. (1983), State of the Union, Islands Business, July: 21-22.

Laracy, H. (Ed) (1989), Ples Blong Iumi Solomon Islands, the Past Four Thousand Years, Suva, Institute of Pacific Studies of the University of the South Pacific.

Leckie, J. (forthcoming), Labour, Regionalism and Internationalism: a Case Study in Fiji, In D. Rubenstein (Ed) Proceedings of the Eighth Pacific History Conference, Guam, December, 1990, University of Guam, Micronesian Area Research Center.

Robie, D. (1986), Unionists on Spy Alert, Islands Business, June: 22-23. 
Sandbrook, R. with Barker, J. (1985), The Politics of Africa's Economic Stagnation, Cambridge, Cambridge University Press.

Sklar, R.L. (1979), The Nature of Class Domination in Africa, The Journal of African Studies. 17(4): 531-552.

Solomon Islands (1973-1976), Annual Reports, Statistical Bulletins, Honiara.

Solomon Islands (1988), Report of the Commission of Inquiry into the World Bank Primary Education Project, Honiara.

Solomon Islands Labour Party (1988), Manifesto, Honiara, National Executive of the Solomon Islands Labour Party.

Tuhanuku, J.T. (1983), Trade Unions and Politics, In P. Larmour with S. Tarua (Eds), Solomon Islands Politics, Suva, Institute of Pacific Studies of the University of the South Pacific.

Tuhanuku, J.T. (1984), Interview with Joses Tuhanuku, General Secretary of the Solomon Islands National Union of Workers, South Pacific Forum, 1(1): 76-93.

Walsh, A.C. (1990), Popiulesin Blong Honiara: Olketa Popiulesin Map Blong 1986 Census. Honiara, Department of Statistics; Palmerston North, Board of Development Studies, Massey University.

Newspapers:

British Solomon Islands News Sheet (1972)

Government Monthly (1983-85)

News drum (1978-82)

Solomons News Drum (1975-76)

Solomon Nius (1985-87)

Solomon Star (1983-86; 1989-91)

Solomons Toktok (1989-91)

The Nius (1987-90) 